\title{
In memoriam: Jan den Boeft 1935-2019
}

The Board of Vigiliae Christianae and the publishing house Brill were deeply saddened to receive news of the passing of Professor Jan den Boeft on 10 August 2019. He was associated with the journal and its book series for three decades and was editor-in-chief from 1990 to 2014.

Jan den Boeft was born in Rotterdam, the city of Erasmus, on 13 October 1935, the only child in a teacher's family. After the war he spent some time in England in order to recover from the Dutch 'hunger winter' of 1944-45, a stay which instilled in him a life-long love of cricket. He first learnt his classical languages at the Marnix Gymnasium in the same city, from where he moved to Leiden in 1953 to study classics, graduating with the highest honours in 1959. During his studies he came under the influence of the great Latinist (and co-founder of this journal), Prof. J. H. Waszink. He decided to focus on Latin language and literature and completed his doctorate entitled Calcidius on Fate: his Doctrine and Sources, under Waszink's supervision in 1970.

In the meantime he had embarked on a career as a teacher of Greek and Latin at the City Gymnasium in Leiden. He taught there from $195^{8}$ to 1976, quickly revealing his considerable didactic and administrative skills, which led to his appointment as Con-Rector at a youthful age. In 1976 he made the move to the tertiary level, obtaining a lectureship in Latin at the University of Utrecht. A decade later, however, he lost this position when the Department of Classics was closed down. There followed some difficult years, when among other things he extended his involvement in local politics, taking on the role of alderman for four years in the borough of Leiderdorp where he then lived. In 1993 his broad knowledge of ancient religion and philosophy was recognised when he was offered the honorary appointment of Professor Extraordinarius in the History of ancient religions in the Theological Faculty of the University of Utrecht, a position he retained until his retirement. But the crown on his academic career was the appointment to the chair of Latin at the Vrije Universiteit, Amsterdam in 1994, where he taught until his retirement in 2000. His inaugural lecture, entitled 'A charming piece of prose in a wholly Ciceronian spirit', focused on a work of the young Erasmus, demonstrating his mastery of the entire Latin tradition from antiquity through to the beginnings of the modern period. 
While a student in Leiden, Den Boeft had formed a close friendship with Father J.C.M. (Bertram) van Winden. It was no surprise, therefore, that Waszink and Van Winden, together with the other editors, invited him in 1986 to become an associate editor of Vigiliae Christianae. By 199 o he was one of the editors-in-chief and not long thereafter he took on the responsibility of co-ordinating the receipt and evaluation of all the contributions submitted to the journal. To this was soon added the task of supervising the publication of monographs in the ever burgeoning Supplements series. It would be difficult to exaggerate the amount of hard work involved in carrying out these tasks, first in combination with his academic duties, and then taking up most of his time during retirement. Manuscripts would even accompany him on his journeys to Italy, which he and his wife Willy would undertake every year in May or June. An indication of his massive contribution is that when he had to give up his role due to the onset of ill-health in 2014, at least three Board members (if not more) were needed in order to take over his tasks. It was a joyous day in 2015 when his contribution was recognised during a ceremony at the Brill offices in Leiden and he accepted a knighthood from the mayor of the city for his services to education and scholarship.

To some degree Den Boeft continued the long tradition of Dutch journal editors, who regarded themselves as capable of making decisions on any manuscript within their chosen area of expertise. He always first read the submissions himself, constantly demonstrating a fine-tuned sense of judgment when evaluating whether they should be published. But he was also scrupulously fair. Whenever an item was in a specialized area or he had any doubts regarding it, he would draw on his extensive network of scholars who were prepared to assist in the process of evaluation. This network was built up over many years mainly through correspondence, for he did not enjoy travelling and seldom left the part of the Netherlands in which he lived and worked (with the exception of the Italian journeys already mentioned).

As a person Jan den Boeft was courteous, considerate, even amiable, but also quite reserved. A very capable and well-spoken man, he gave the impression of being in complete control of his situation. This was reinforced by a dry sense of humour, often encapsulated in witty turns of phrase. But those few who knew him better, did come to realize that underneath he was a bit of a worrier. A symptom of this perhaps was his refusal to drive a car or fly in an aeroplane. This trait was no doubt exacerbated by the sense of responsibility he felt in relation to the tasks that he took upon himself. But it also meant that he carried out those tasks very conscientiously and very well. This journal, its readers and its publishers were the beneficiaries. And it would not be fitting to end this brief sketch without noting his great love of and loyalty to both the 
classical and the Christian traditions, the two traditions that come together in the field of studies covered by this journal. For Den Boeft his editorial work was a concrete expression of that love, together with his teaching and his many scholarly contributions.

The members of the Board extend their condolences to his wife, Willy den Boeft-van den Dool. They met while students in Leiden and for over fifty years she gave unstinting support to his scholarly endeavours. The Board acknowledges the contributions of Jan den Boeft with gratitude and will strive to continue the work of the journal in the spirit that he embodied over a period of so many years. 